\title{
Correlation Between Total Phenols Content, Antioxidant Power and Cytotoxicity
}

\author{
Mohyelden A. Osman ${ }^{1, *}$ (D), Ghada I. Mahmoud ${ }^{1}$ (D), Shaimaa S. Shoman ${ }^{1}$ (D) \\ 1 Biochemistry Department, Faculty of Agriculture, Cairo University, Egypt; osmanmoa@yahoo.com (M.A.O.); \\ ghadaibrahiim@yahoo.com (G.I.M.); shimaa_shoman88@cu.edu.eg (S.S.S.); \\ * Correspondence: osmanmoa@yahoo.com;
}

Scopus Author ID 57218990625

Received: 11.10.2020; Revised: 2.11.2020; Accepted: 4.11.2020; Published: 7.11.2020

\begin{abstract}
Plants are commonly used in traditional medicines against diseases according to their cytotoxic effect. Therefore, studying the relationship between antioxidant activity and cytotoxicity is remaining interesting to find a simple indicator for plant cytotoxicity. The objective of this study is to give scientific evidence of the correlation between antioxidant activity and cytotoxicity in 10 different plants. Phytochemical screening of $70 \%$ ethanolic extracts (EEs) has been shown to be rich in steroids, terpenoids, flavonoids, tannins, and phenols. The antioxidant activity of EEs gave $\mathrm{IC}_{50}$ ranged between 42.33 (Ipomoea batatas) and 1,519.76 $\mathrm{g} \mathrm{ml}^{-1}$ (Citrullus colocynthis) by DPPH method and 31.60 (Avicennia marina) and $1,133.79 \mu \mathrm{g} \mathrm{ml}^{-1}$ (Cichorium endivia L.) by ABTS method. The total phenolic content of EEs was ranged between $8.72 \pm 0.08$ (Daucus carota L.) and $91.67 \pm 0.13$ (Avicennia marina) as $\mathrm{mg}$ GAE $\mathrm{g}^{-1}$ dried sample. The Pearson's correlation coefficient (r) between antioxidant activity $\left(\mathrm{IC}_{50}\right)$ as related to total phenolic content was strongly correlated, moderately correlated with brine shrimp cytotoxicity, weakly correlated with carcinogenic liver and breast cells cytotoxicity, and weakly or moderately correlated with antimicrobial activity. These results proved that the total phenolic content could be indicating the antioxidant scavenging activity but not the cytotoxic effect.
\end{abstract}

Keywords: anticancer; Artemia salina; HepG2; MCF-7; radical scavenging.

(C) 2020 by the authors. This article is an open-access article distributed under the terms and conditions of the Creative Commons Attribution (CC BY) license (https://creativecommons.org/licenses/by/4.0/).

\section{Introduction}

For decades, the consumption of herbal plants has drawn an avalanche of interest as they could accommodate therapeutic response by reducing the risk of chronic human illnesses such as certain types of cancers, inflammation, cardiovascular and neurodegenerative diseases and claimed for treatments of a number of symptoms, including asthma, hypertensive, indigestion, laxative peptic ulcer, diarrhea, and bacterial infection. Thus they are promising candidates to be developed as pharmaceutical products [1-3].

Free radicals have been accused of initiating many serious diseases by driving oxidative stresses; more ever free radicals play harmful physiological responses which may lead to developing cell damages and various diseases such as diabetes, atherosclerosis, ischemic injury, inflammation, and carcinogenesis [1, 6-8]. It has been known that phenolic and flavonoid compounds of the plant extracts are responsible for the antioxidant effect [9-14]. Phytochemicals from fruits and vegetables and herbs significantly reduce the risk of chronic disease development, probably due to their antioxidant properties [15-19]. This is the reason that is considerable scientific and commercial interest in discovering new antioxidant and therapeutic agents, which could be considered as strong antioxidant and anti-proliferative 
molecules from natural product sources [3, 20]. The ancient Egyptians were aware of the usefulness of many medicinal plants in the treatment of various diseases; they used the plant parts such as leaves, rhizomes, seeds, roots, flowers, fruits, and oils in the form of pastes, powders, suppositories, pills, creams, and ointments. Nowadays, in Egypt, many plant species are used in folk medicine and are sold at markets and herbal vendors [21].

Different plant extracts were reported to possess antioxidant activity [22-24], the antimicrobial effect [25-28], and cancer cell toxicity [29-32]. Furthermore, some biological assays were correlated with the phytochemicals of these plant extracts [33, 34].

During the course of the search for bioactive compounds that could be used as anticancer drugs or for treatment of cancer, 10 different Egyptian plants were used in this study. The correlation between antioxidant activity, total phenols as related to cytotoxicity was carried out. To find the scientific evidence for the correlation between its cytotoxicity and total phenolics (antioxidant activity) by in-vivo assays (Brine shrimp toxicity, antimicrobial activity) and by in-vitro assays (anticancer activity against carcinogenic liver and breast cells), correlation coefficient was investigated.

\section{Materials and Methods}

\subsection{Chemicals and instruments.}

Solvents and standards used throughout this study were purchased from different companies of adequate analytical grade or distilled before use. 1, 1-diphenyl, 2-picrylhydrazyl radical (DPPH), ascorbic acid, ABTS, and neutral red were purchased from Sigma Chemical Co. Spectrophotometric measurements were performed using a Uv-Vis spectrophotometer (Spectronic Helios Gamma, Thermo Scientific) and a microplate reader (BioTek, ELX808).

\subsection{Plant material.}

Samples of 10 plant species were collected during January, May, June, and September 2018. The authentication of plants was confirmed by Flora and Phyto-Taxonomy Department, Agricultural Museum, Dokki, Cairo, Egypt (Table 1).

\subsection{Extraction and samples preparation.}

The dried powdered sample of 10 plants sample (200 g dry weight) was extracted three times with $1 \mathrm{~L}$ each of ethanol $70 \%$ with shaking for 12 hours then collected and filtered. The yield of ethanolic extracts was calculated - the ethanolic extracts used for phytochemical screening, antioxidant activity, and determination of total phenols. The extract of each sample was used for cytotoxicity tests, i.e., brine shrimp toxicity, antimicrobial, and anticancer cell assays.

\subsection{Phytochemical screening.}

The ethanolic extracts of plant samples were used for the detection of alkaloids, anthraquinones, saponins, glycosides, phenols, tannins, and reducing sugars according to [35], steroids and terpenoids [36], anthocyanins [37], coumarins [38], and flavonoids [39]. 


\subsection{Total phenolic content.}

The total phenolic content (TPC) of the ethanolic extracts was measured using the Folin-Ciocalteu method as described by [40]. All samples were prepared and measured in triplicate. Gallic acid was used as a standard. Stock standard solution of gallic acid and working standards were prepared. The extracts were prepared at a concentration of one $\mathrm{mg} \mathrm{ml}^{-1} .100 \mu \mathrm{L}$ of extract, transferred to a test tube, and $0.75 \mathrm{~mL}$ of Folin-Ciocalteu reagent (previously diluted 10 -fold with deionized water) was added and mixed.

Table 1. List of plant species used in the study.

\begin{tabular}{|c|c|c|c|c|}
\hline $\begin{array}{l}\text { Plant species } \\
\text { (scientific name) }\end{array}$ & Family name & Common name & Collection area & Used part \\
\hline $\begin{array}{l}\text { Avicennia marina } \\
\text { (Forssk.) Vierh. }\end{array}$ & Avicenniaceae & Mangrove & Red sea coast & leaves \\
\hline $\begin{array}{l}\text { Calotropis procera } \\
\text { (Ait.) Ait. fil. }\end{array}$ & Apocynaceae & Rooster tree & $\begin{array}{l}\text { Public area in } \\
\text { Cairo }\end{array}$ & leaves \\
\hline Cichorium endivia $\mathbf{L}$. & Compositae & Endive, escarole & $\begin{array}{l}\text { Faculty of } \\
\text { Agriculture farm }\end{array}$ & leaves \\
\hline $\begin{array}{l}\text { Citrullus colocynthis } \\
\text { (L.) Schrad }\end{array}$ & Cucurbitaceae & $\begin{array}{l}\text { Bitter apple, bitter } \\
\text { cucumber }\end{array}$ & $\begin{array}{l}\text { Herbarium store } \\
\text { in Cairo }\end{array}$ & Fruits \\
\hline Daucus carota $\mathrm{L}$. & Umbelliferae & Wild carrot & Market & Seeds \\
\hline Ficus carica $\mathbf{L}$. & Moraceae & Common fig & $\begin{array}{l}\text { Faculty of } \\
\text { Agriculture farm }\end{array}$ & leaves \\
\hline $\begin{array}{l}\text { Ipomoea batatas (L.) } \\
\text { Lam. }\end{array}$ & Convolvulaceae & Sweet Potato & $\begin{array}{l}\text { Faculty of } \\
\text { Agriculture farm }\end{array}$ & leaves \\
\hline Jatropha curcas $\mathbf{L}$. & Euphorbiaceae & $\begin{array}{l}\text { Physic nut, Barbados nut, } \\
\text { poison nut or purging nut }\end{array}$ & $\begin{array}{l}\text { Faculty of } \\
\text { Agriculture farm }\end{array}$ & leaves \\
\hline $\begin{array}{l}\text { Simmondsia chinensis } \\
\text { (Link) C.K. Shneid }\end{array}$ & Simmondsiaceae & Jojoba & $\begin{array}{l}\text { Faculty of } \\
\text { Agriculture farm }\end{array}$ & leaves \\
\hline Vitis vinifera $\mathrm{L}$. & Vitaceae & Grape & $\begin{array}{l}\text { Faculty of } \\
\text { Agriculture farm }\end{array}$ & leaves \\
\hline
\end{tabular}

The mixture was allowed to stand at room temperature for $5 \mathrm{~min}$. Then, $0.75 \mathrm{~mL}$ of $6 \%$ (w/v) sodium carbonate was added to the mixture and mixed gently. After standing at room temperature for $90 \mathrm{~min}$, the absorbance was read at $725 \mathrm{~nm}$ using UV/Vis spectrophotometer. The standard calibration curve of gallic acid $\left(0.01-0.05 \mathrm{mg} \mathrm{mL}^{-1}\right)$ was plotted. The total content of phenolic compounds of EE was calculated as mg gallic acid equivalent per $\mathrm{g}$ dry weight (GAE g-1 D. W.).

\subsection{Antioxidant activity.}

\subsubsection{DPPH radical scavenging assay.}

Scavenging activity was determined by [41] using 1, 1-diphenyl, 2-picrylhydrazyl free radical (DPPH'). A portion of $0.1 \mathrm{ml}$ of various concentrations of tested samples $(200,400$, 600,800 , and $1,000 \mathrm{ppm}$ in $0.1 \mathrm{ml}$ ) was added to $0.9 \mathrm{ml}$ of $0.1 \mathrm{mmol}$ solutions of DPPH in methanol. As well as methanol, only $0.1 \mathrm{ml}$ was used as control. After 30 minutes of incubation at room temperature, the absorbance at $517 \mathrm{~nm}$ was recorded. Ascorbic acid was used as a standard reference. The percent inhibition was calculated from the following equation:

$\%$ inhibition $=[($ Absorbance of control - Absorbance of test sample $) /$ Absorbance of control $] \times 100$.

The concentration (ppm) required to reduce $50 \%$ of $\mathrm{DPPH}^{\bullet}$ activity was determined $\left(\mathrm{IC}_{50}\right)$. 


\subsubsection{ABTS radical scavenging assay.}

The radicals scavenging activity of the $70 \%$ ethanolic extracts against radical cation $\left(\mathrm{ABTS}^{+}\right)$were measured using the methods of [42] with some modifications. ABTS radical was prepared by reacting ABTS solution $\left(7 \mathrm{mmol} \mathrm{L}^{-1}\right)$ with potassium persulphate $(2.45 \mathrm{mmol}$ $\mathrm{L}^{-1}$ ), and the mixture would be kept at room temperature in the dark for 16 hours. The ABTS solution was diluted with ethanol to an absorbance of $0.70 \pm 0.02$ at $734 \mathrm{~nm}$, in the moment of use. Each sample $(0.1 \mathrm{ml})$ with various concentrations $\left(0-1.0 \mathrm{mg} \mathrm{ml}^{-1}\right)$ were added to $1 \mathrm{ml}$ of ABTS solution and mixed vigorously. After 6 min at room temperature, the absorbance at 734 $\mathrm{nm}$ was measured. The ABTS scavenging activity was calculated by the following formula:

$\%$ inhibition $=[($ Absorbance of control - Absorbance of test sample $) /$ Absorbance of control $] \times 100$.

The concentration (ppm) required to reduce $50 \%$ of ABTS radical activity was determined $\left(\mathrm{IC}_{50}\right)$.

\subsection{Cytotoxicity assays.}

\subsubsection{Brine shrimp.}

Shrimp eggs (Artemia salina) were bought from a local aquarium store. Toxicity assay of the ethanolic extracts of 10 plant samples and potassium chromate as positive control were carried out as described by [43]. Samples of each extract were tested initially at concentrations of $0,25,50,100,200,400,600,800$ and $1,000 \mathrm{ppm}\left(\mu \mathrm{g} \mathrm{mL}^{-1}\right)$ in flasks containing $10 \mathrm{ml}$ of $3.5 \%$ artificial seawater (solution of $\mathrm{NaCl}$ ) and 10 shrimp eggs. The test flasks were left uncovered under the lamp. Hatched nauplii were counted after 48 hours.

\subsubsection{Anticancer activity.}

Cell culture Human transformed cell lines from the liver (hepatocellular; HepG2), breast (MCF-7) cell lines were obtained from Vaccera (Giza, Egypt). Cells were grown under aseptic conditions in DMEM (Dulbecco's Modified Eagle Medium) supplemented with 10\% Fetal bovine serum and $1 \%$ antibiotic (penicillin $\mathrm{G}$ potassium and streptomycin) in a humidified atmosphere and $5 \% \mathrm{CO}_{2}$ at $37^{\circ} \mathrm{C}$ with a complete medium in a $25 \mathrm{~cm}^{3}$ cell culture flask. Cytotoxicity assay of 10 plant samples ethanolic extracts were tested against MCF-7 and HepG2 cells by the neutral red assay as described by [44]. Cultured monolayer at $80 \%$ confluence subjected to wash with Phosphate-buffered saline (PBS), then trypsinized by $2 \mathrm{ml}$ $(0.25 \%)$ trypsin-EDTA solution, incubated for $2 \mathrm{~min}$. Cells were collected and plated in 96well plate at about 20,000 cells per well, then the plate incubated for 24 hours. Cells were treated with each tested sample in different concentrations and media as a negative control then incubated at $37{ }^{\circ} \mathrm{C}$ for 24 hours. After several washings, neutral red medium $\left(40 \mu \mathrm{g} \mathrm{ml}^{-1}\right)$ was added into each well and incubated again for 3 hours at $37{ }^{\circ} \mathrm{C}$. The dye-containing medium was decanted, and each well was rinsed with PBS. Ethanol/deionized water/glacial acetic acid (50:49:1) destaining solution was used, and the absorbance of acidified ethanol solution containing extracted neutral red dye was measured using a microplate reader at $540 \mathrm{~nm}$, and cell viability was calculated according to the following equation:

$\%$ cytotoxicity $=$ Absorbance of control cells - Absorbance of treated cells/Absorbance of control cells $\times 100$

The $\mathrm{IC}_{50}$ values were calculated by linear regression. 


\subsubsection{Antimicrobial activity.}

The Susceptibility tests were carried at RCMB, Regional Center for Mycology and Biotechnology. The tests were performed on the 10 plant samples ethanolic extracts according to NCCLS recommendations [45]. Screening tests regarding the inhibition zone were carried out by the well diffusion method [46] against six types of microorganisms; Aspergillus fumigatus (RCMB 002008) and Candida albicans RCMB 005003 (1) ATCC 10231 as a fungi strains, Staphylococcus aureus ( RCMP 010010) and Bacillus subtilis RCMB 015 (1) NRRLB543 as a gram-positive bacteria, Escherichia coli (RCMB 010052) ATCC 25955 and Proteus vulgaris RCMB 004 (1) ATCC 13315 as a gram-negative bacteria. The inoculum suspension was prepared from colonies grown overnight on an agar plate and inoculated into MuellerHinton broth (fungi using malt broth). A sterile swab was immersed in the suspension and used to inoculate Mueller-Hinton agar plates (fungi using malt agar plates). The extracts were dissolved in dimethyl sulfoxide (DMSO) with a concentration of $40 \mathrm{mg} \mathrm{ml}^{-1}$. The well diameter was $6 \mathrm{~mm}$ (100 $\mu \mathrm{l}$ was tested). The positive control for fungi is ketoconazole $\left(100 \mu \mathrm{g} \mathrm{ml}^{-1}\right)$, for bacteria is gentamycin $\left(4 \mu \mathrm{g} \mathrm{ml}^{-1}\right)$, and the negative control was DMSO. The inhibition zone was measured around each well after 24 hours at $37^{\circ} \mathrm{C}$.

\subsection{Statistical analysis.}

Values are presented as means \pm SEM. Statistical analysis was carried out by using the "costat" statistic computer program. Statistical analysis was based on One-way ANOVA followed by the student-Newman Keuls test. The value of the probability of less than $5 \%(\mathrm{P}<$ 0.05 ) was considered statistically significant. Pearson's correlation coefficient was conducted to find the relationship between antioxidant activity and cytotoxicity. The correlation coefficient with a negative value indicates a negative linear correlation, a positive value indicates a positive linear correlation, 0 indicates no linear correlation, 0-0.3 indicates a weak linear correlation, 0.3-0.7 indicates a moderate linear correlation, and 0.7-1 indicates a strong correlation [47].

\subsection{Ethical approval.}

This study protocol with the approval code of CU I F Reg. 120 of the invertebrate animal was registered by Cairo University Institutional Animal Care and Use Committee (CUIACUC). CU-IACUC is organized and operated according to the World Organization for Animal Health (OIE) and Guide for the Care and Use of Laboratory Animals 8th Edition 2011 (the Guide).

\section{Results and Discussion}

\subsection{Phytochemical screening.}

Various chemical reactions were carried out to detect and identify the presence or absence of bioactive compounds in the studied plant's ethanolic extracts. The results shown in Table 2 indicate that Avicennia marina (leaves) extract is the richest extract of bioactive compounds that contains appreciable amounts of phenols, glycosides, alkaloids, coumarins, anthocyanins, tannins, flavonoids, steroids, and terpenoids, while anthraquinone was not detected in the ten extracts. These results coincide with [48]; the shoot ethanolic extract of 
Avicennia marina revealed the presence of tannins, sterols, flavones, and glycosides. The obtained related results could be due to the similarity in the growing zone (red sea, Egypt).

Table 2. Phytochemical screening of ethanolic extract of 10 plant samples.

\begin{tabular}{|c|c|c|c|c|c|c|c|c|c|c|c|}
\hline \multirow[t]{2}{*}{$\begin{array}{l}\text { Class of } \\
\text { compounds }\end{array}$} & $\begin{array}{l}D . \\
\text { carota } \\
\text { (seeds) }\end{array}$ & $\begin{array}{l}\text { C. } \\
\text { procera } \\
\text { (leaves) }\end{array}$ & \multirow[t]{2}{*}{$\begin{array}{l}\text { C. endivia } \\
\text { L. (leaves) }\end{array}$} & \multirow[t]{2}{*}{$\begin{array}{l}\text { A. } \\
\text { marina } \\
\text { (leaves) }\end{array}$} & \multirow[t]{2}{*}{$\begin{array}{l}\text { I. batatas } \\
\text { (leaves) }\end{array}$} & \multicolumn{2}{|c|}{$\begin{array}{l}\text { C. colocynthis } \\
\text { (fruits) }\end{array}$} & \multirow[t]{2}{*}{$\begin{array}{l}J . \\
\text { curcas } \\
\text { (leaves) }\end{array}$} & $\begin{array}{l}F \text {. carica } \\
\text { (leaves) }\end{array}$ & $\begin{array}{l}\text { S. } \\
\text { chinensis } \\
\text { (leaves) }\end{array}$ & \multirow[t]{2}{*}{$\begin{array}{l}V . \\
\text { vinifera } \\
\text { (leaves) }\end{array}$} \\
\hline & Degree & intensity & & & & & & & & & \\
\hline $\begin{array}{l}\text { Steroids and } \\
\text { terpenoids }\end{array}$ & + & +++ & + & +++ & +++ & + & + & & +++ & +++ & ++ \\
\hline Flavonoids & + & + & + & +++ & ++ & + & + & & ++ & + & ++ \\
\hline Tannins & + & + & + & +++ & +++ & + & + & & ++ & ++ & ++ \\
\hline Saponins & - & - & + & - & - & - & + & & - & - & - \\
\hline Anthocyanin & - & - & - & +++ & - & - & - & & - & - & - \\
\hline Coumarin & + & ++ & + & +++ & +++ & + & ++ & & ++ & ++ & ++ \\
\hline Alkaloids & +++ & +++ & +++ & +++ & +++ & +++ & +++ & & +++ & +++ & +++ \\
\hline $\begin{array}{l}\text { Anthraquino } \\
\text { ne }\end{array}$ & - & - & - & - & - & - & - & & - & - & - \\
\hline Glycosides & + & +++ & + & +++ & ++ & + & & & + & +++ & ++ \\
\hline Phenols & + & ++ & + & +++ & +++ & ++ & & ++ & ++ & +++ & ++ \\
\hline
\end{tabular}

$(-)$ not detected, $(+)$ traces, $(++)$ low concentration, $(+++)$ high concentration

\subsection{Total phenolics.}

The phytochemical screening of ethanolic extracts indicated the presence of many phenolic classes of compounds. Hence, the quantitative determination of total phenols and antioxidant activity were determined (Table 3). The significantly high total phenolic content of $70 \%$ ethanolic extracts of Avicennia marina (leaves), Simmondsia chinensis (leaves), and Ipomoea batatas (leaves) has amounted to $91.67 \pm 0.13,49.09 \pm 0.25$, and $49.64 \pm 0.23 \%$, respectively ( $\mathrm{mg} \mathrm{GAE} \mathrm{g}^{-1}$ dried sample). The total phenolic content obtained for Avicennia marina leaves ethanolic extract was higher than that obtained by [49] (22.82 $\left.\pm 1.8 \mathrm{mg} \mathrm{g}^{-1}\right)$, which could be due to the difference in the growing zone (Taiwan) or atmospheric conditions.

\subsection{Antioxidant activity IC50.}

The $\mathrm{IC}_{50}$ or concentration that causes a decrease in the initial DPPH or ABTS concentration by $50 \%$ was determined by plotting of concentration (ppm) of leaves against percent reduction of DPPH or ABTS. The results showed that the high phenolic content of Avicennia marina ethanolic extract was conflicted with high antioxidant activity with low $\mathrm{IC}_{50}$ values. Figure 1 showed the determination of $\mathrm{IC}_{50}$ of Avicennia marina extract by DPPH and ABTS methods, respectively. [50] reported that the $\mathrm{IC}_{50}$ obtained for water extract of Avicennia marina (Forsk.) Vierh. leaves $\left(271.71 \mu \mathrm{g} \mathrm{mL}^{-1}\right)$ by the DPPH method was higher than that obtained in this study $\left(53.22 \mu \mathrm{g} \mathrm{mL}^{-1}\right)$, which may be due to different extract solvent (ethanol) and different zone of plant collection (Egypt).

Table 3. The ethanolic extract (70\%) extraction percentage of 10 plant samples, total phenolic content (mg GAE $\mathrm{g}^{-1}$ dried sample) by Folin -Ciocalteu method, and antioxidant activity by DPPH and ABTS methods.

\begin{tabular}{|c|c|c|c|c|c|c|c|c|c|c|}
\hline \multirow{3}{*}{$\begin{array}{l}\text { Plant samples } \\
\text { Avicennia marina }\end{array}$} & \multirow{2}{*}{\multicolumn{4}{|c|}{ Extraction percentage (\%) }} & \multirow{2}{*}{\multicolumn{4}{|c|}{$\begin{array}{l}\text { Total phenolic content (mg } \\
\text { GAE } \mathrm{g}^{-1} \text { dried sample) }\end{array}$}} & \multicolumn{2}{|c|}{$\begin{array}{l}\text { Antioxidant activity } * \mathrm{IC}_{50}(\mu \mathrm{g} \\
\left.\mathrm{ml}^{-1}\right)\end{array}$} \\
\hline & & & & & & & & & \multirow{2}{*}{$\begin{array}{l}\text { DPPH method } \\
53.22\end{array}$} & \multirow{2}{*}{$\begin{array}{l}\text { ABTS method } \\
31.60\end{array}$} \\
\hline & 40.24 & \pm & 0.83 & $\mathrm{a}$ & 91.67 & \pm & 0.13 & $\mathrm{a}$ & & \\
\hline Calotropis procera & 31.53 & \pm & 1.68 & $\mathrm{~b}$ & 19.07 & \pm & 0.04 & ef & $1,138.95$ & 818.33 \\
\hline Cichorium endivia $\mathrm{L}$. & 21.42 & \pm & 0.33 & $\mathrm{c}$ & 9.27 & \pm & 0.08 & $\mathrm{~h}$ & 878.73 & $1,133.79$ \\
\hline Citrullus colocynthis & 27.33 & \pm & 1.15 & $\mathrm{bc}$ & 23.15 & \pm & 0.13 & $\mathrm{~d}$ & $1,519.76$ & 720.46 \\
\hline Daucus carota & 22.77 & \pm & 1.70 & $\mathrm{c}$ & 8.72 & \pm & 0.08 & $\mathrm{i}$ & $1,133.79$ & 708.22 \\
\hline Ficus carica & 26.32 & \pm & 0.99 & $\mathrm{c}$ & 16.28 & \pm & 0.18 & $\mathrm{e}$ & 793.65 & 668.45 \\
\hline
\end{tabular}




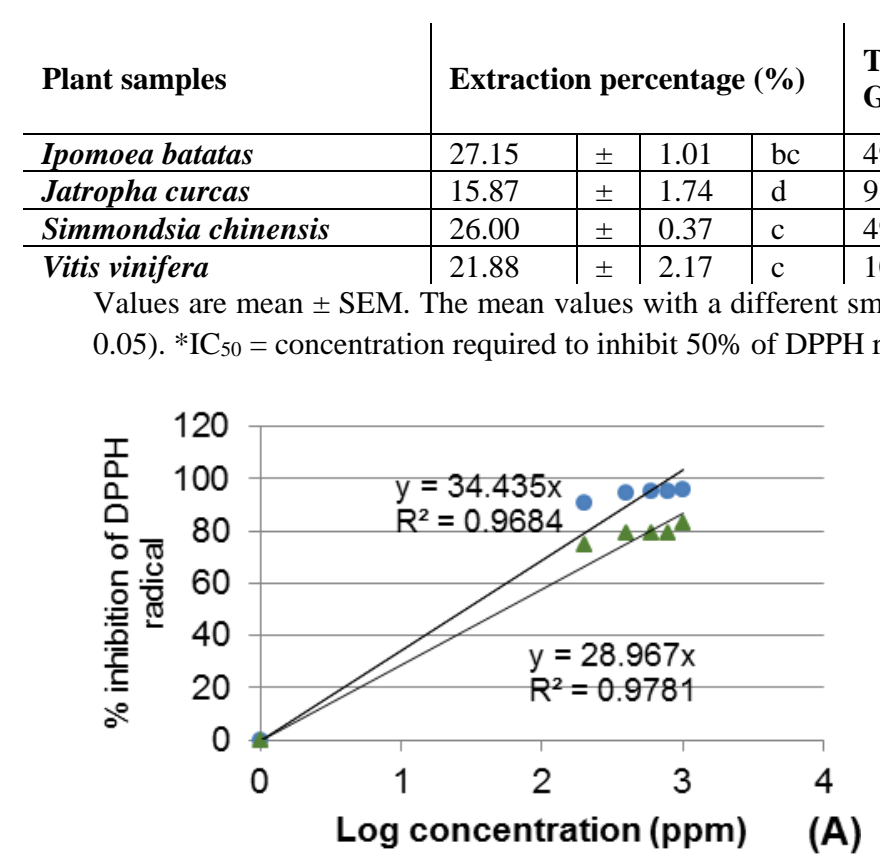

\begin{tabular}{|l|l|l|l|l|l}
\multirow{6}{*}{$\begin{array}{l}\text { Total phenolic content }(\mathbf{m g} \\
\text { GAE } \mathbf{g}^{-1} \text { dried sample) }\end{array}$} & $\begin{array}{l}\text { Antioxidant activity } * \text { IC50 }(\boldsymbol{\mu g} \\
\left.\mathbf{m l}^{-1}\right)\end{array}$ \\
\cline { 3 - 6 } & $\mathbf{D P P H}$ method & ABTS method \\
\hline 49.64 & \pm & 0.23 & $\mathrm{c}$ & 42.33 & 36.00 \\
\hline 9.44 & \pm & 0.11 & $\mathrm{f}$ & 827.81 & $1,008.06$ \\
\hline 49.09 & \pm & 0.25 & $\mathrm{~b}$ & 95.27 & 38.51 \\
\hline 10.89 & \pm & 0.05 & $\mathrm{~g}$ & $1,089.33$ & 696.38
\end{tabular}

Values are mean \pm SEM. The mean values with a different small letter within a column indicate significant differences ( $\mathrm{p}<$

$0.05)$. ${ }^{\mathrm{I}} \mathrm{C}_{50}=$ concentration required to inhibit $50 \%$ of DPPH radical (DPPH method), ABTS radical (ABTS method).

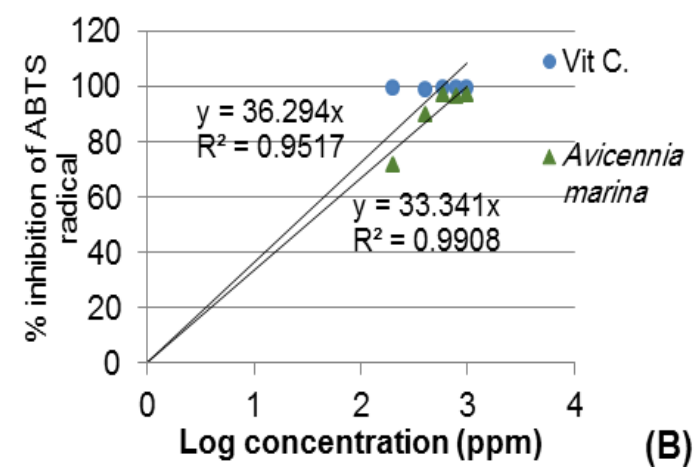

Figure 1. Determination of $\mathrm{IC}_{50}$ of vit. $\mathrm{C}$ and Avicennia marina leaves ethanolic extract from the linear correlation between log concentration versus inhibition percent; (A) by DPPH method; (B) by ABTS method.

\subsection{Correlations.}

\subsubsection{The correlation between DPPH and ABTS.}

The correlation between antioxidant activity by two methods (DPPH and ABTS) was determined (Figure 2). The result showed that the two methods were supported by each other with a strong positive correlation. This positive correlation was in agreement with [51]; they found a descending order of different extract solvents used for determination of the antioxidant potential of Spirulina platensis in both commonly use radical methods (DPPH and ABTS).

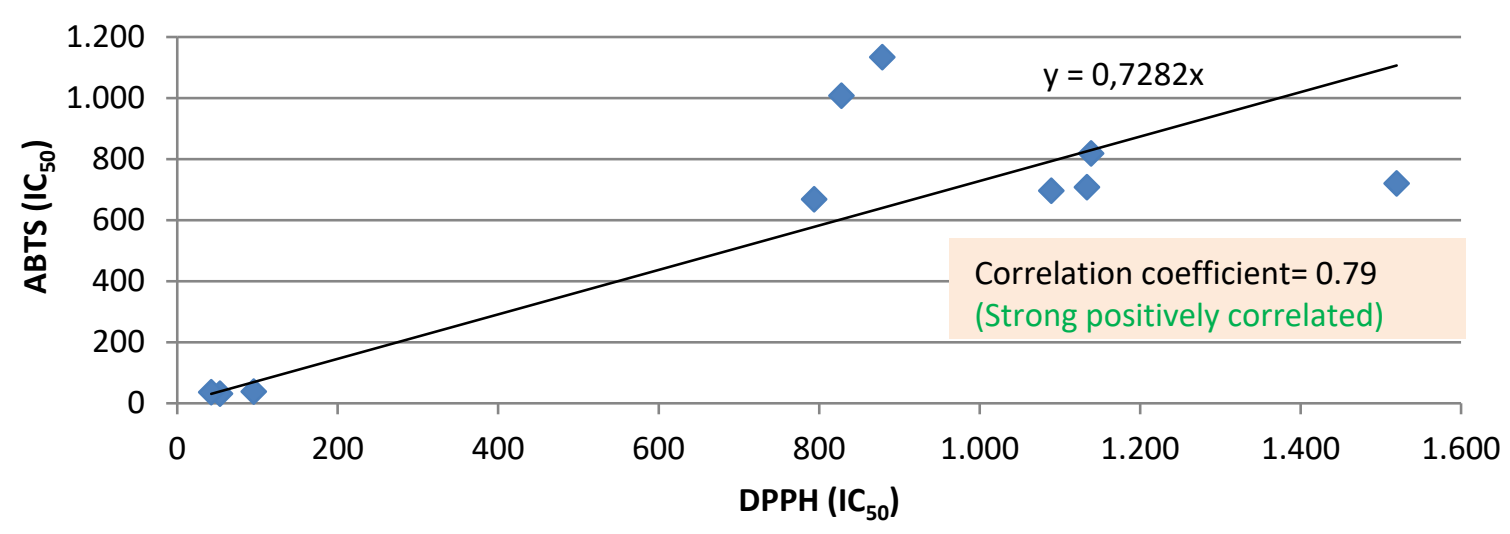

Figure 2. Correlation between DPPH and ABTS methods used for the determination of antioxidant activity.

3.4.2. The correlation between antioxidant activity and total phenols.

As expected from the last result, the correlation between antioxidant activity $\mathrm{IC}_{50}$ and total phenolic content ( $\mathrm{mg} \mathrm{GAE} \mathrm{g}^{-1}$ dried sample) was in a strong negative correlation with a correlation coefficient of 0.78 by DPPH method and 0.86 ABTS method (Figure 3). [52] proved that there is a significant relationship between total phenolic content and antioxidant activity; they suggested that it is due to the phenolic compounds' major contribution to antioxidant properties of the used plant. In contrast, [53] reported that the extracts with high total phenolic 
content showed high radical scavenging activity, but by using linear regression analysis, they found that there is no direct correlation found between antioxidant properties and total phenolic compounds quantity. The plant extracts formed from very complex mixtures of different molecules, the proton donating hydroxyl groups with a particular position in the structure of molecules, might be controlling the radical scavenging properties of these extracts [53].

\subsubsection{The correlation between antioxidant activity and cytotoxicity.}

\subsubsection{The correlation between antioxidant activity and brine shrimp cytotoxicity.}

Toxicity assay of the ethanolic extracts and potassium chromate as a positive control were carried out. The results showed in Figure 4 indicated the sensitivity of this assay. Jatropha curcas L. (leaves), Ipomoea batatas (leaves), Simmondsia chinensis (leaves), Avicennia marina (leaves), and Cichorium endivia L. (leaves) ethanolic extracts showed significant cytotoxic effect compared with other ethanolic extracts. On the other hand, Calotropis procera (leaves) ethanolic extract was virtually non-toxic on the shrimps hatching and exhibited very low toxicity.
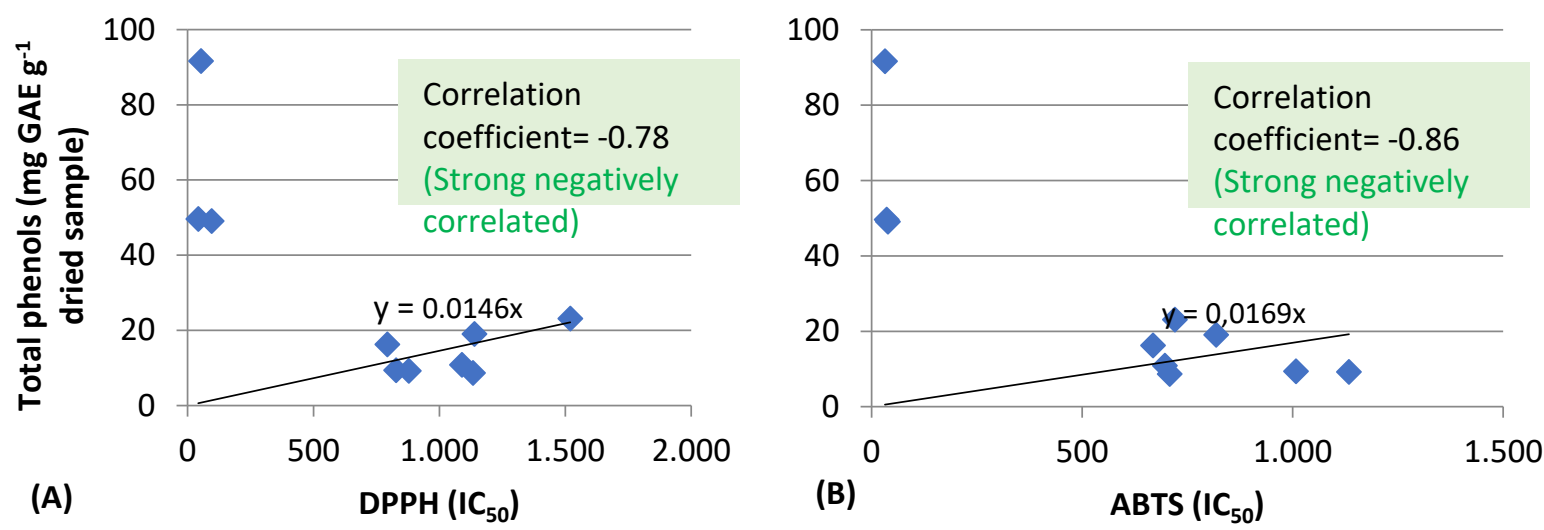

Figure 3. Correlation between antioxidant activity and total phenols (mg GAE g ${ }^{-1}$ dried sample); (A) by DPPH method; (B) by ABTS method.

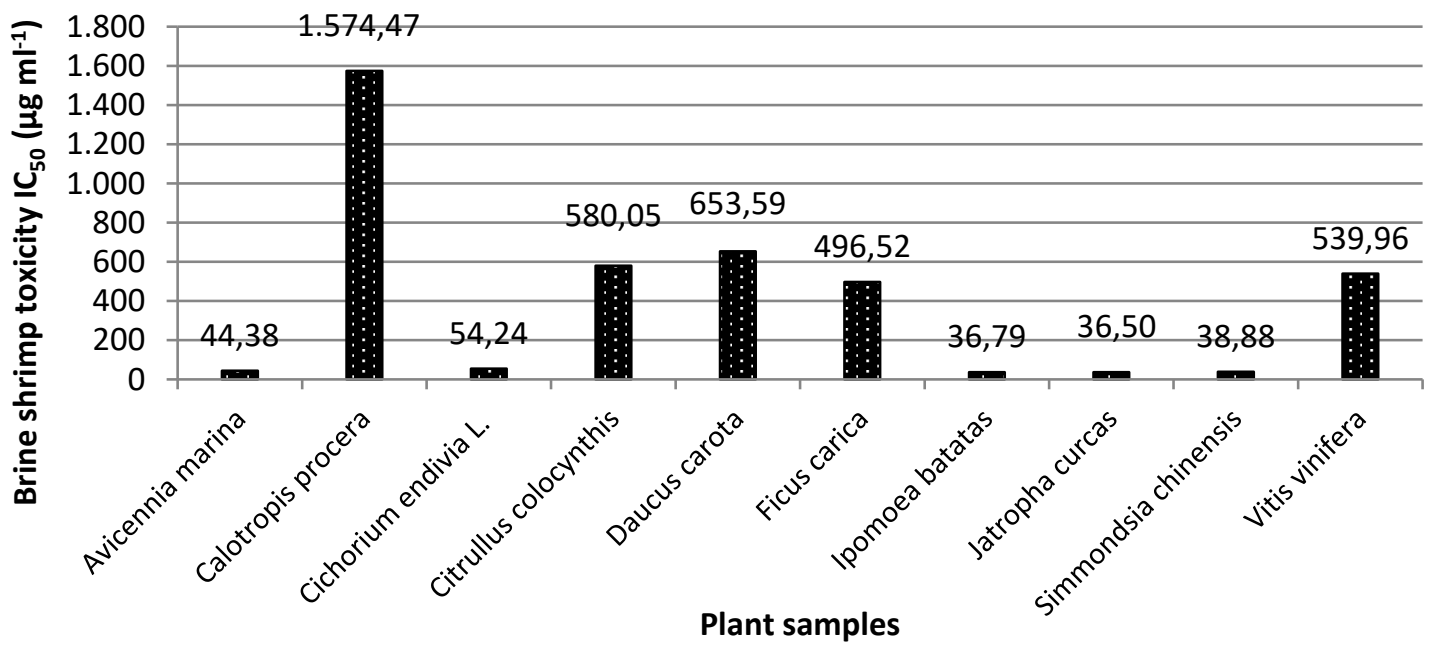

Figure 4. In vivo cytotoxicity assay $\mathrm{IC}_{50}\left(\mu \mathrm{g} \mathrm{ml}^{-1}\right)$ by brine shrimp hatching cytotoxicity assay of 10 plant samples.

The Pearson's correlation coefficient between antioxidant activity by DPPH method and brine shrimp toxicity assay $\mathrm{IC}_{50}\left(\mu \mathrm{g} \mathrm{ml}^{-1}\right)$ was calculated and showed in Figure 5. The results indicated a moderately positive correlation, according to [47]. 


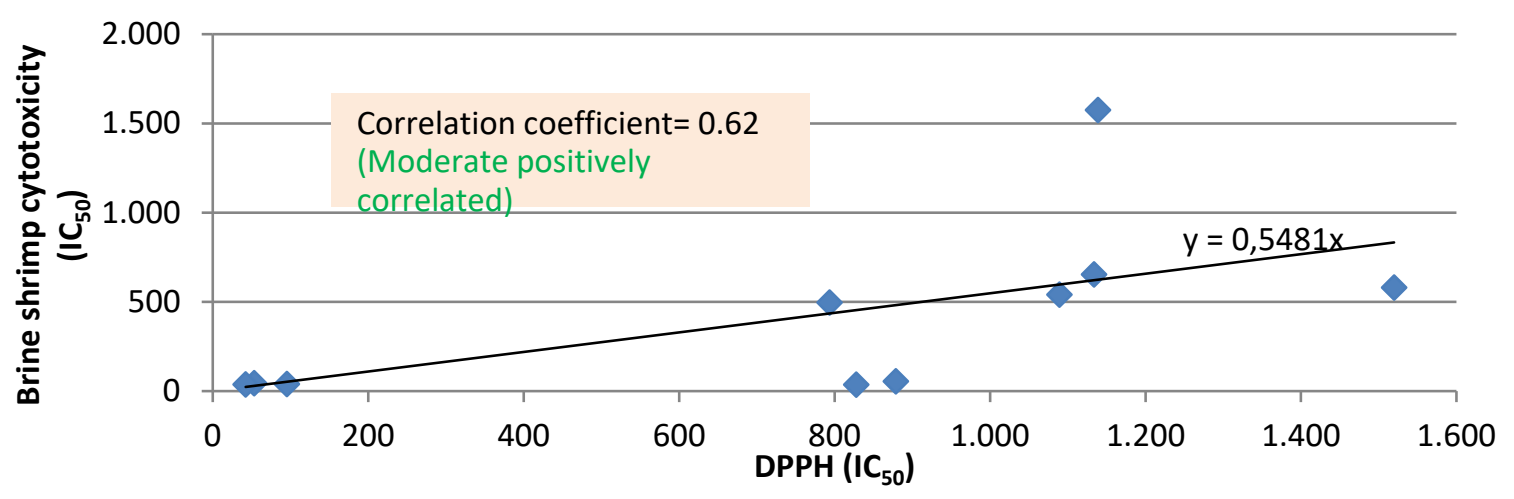

Figure 5. Correlation between antioxidant activity by DPPH method and brine shrimp toxicity assay $\mathrm{IC}_{50}(\mu \mathrm{g}$ $\left.\mathrm{ml}^{-1}\right)$.

Since the total phenols were found to be strongly correlated with antioxidant activity either (DPPH or ABTS), it was expected to be the same correlation of phenols and $\mathrm{IC}_{50}$ to any of the studied parameters.

3.4.3.2. The correlation between antioxidant activity and breast and liver cancer cell line cytotoxicity.

In vitro (neutral red cytotoxicity assay) and in vivo (brine shrimp hatching cytotoxicity assay and antimicrobial activity by well diffusion method including microbial and fungal strains) assays were used in finding the relationship between antioxidant activity and cytotoxicity. Figure 6 showed the cytotoxic effects of 10 plants ethanolic extracts against liver (HepG2) and breast cell lines (MCF-7) expressed as IC50.

Calotropis procera (leaves) and Citrullus colocynthis (fruits) ethanolic extracts possessed the highest cytotoxic effect against liver cancer cells with $\mathrm{IC}_{50}$ of 38.24 and 101.23 $\mu \mathrm{g} \mathrm{ml}^{-1}$, respectively, and breast cancer cells with IC50 of 51.02 and $21.71 \mu \mathrm{g} \mathrm{ml}^{-1}$, respectively. The results proved that the increase in concentrations of extracts exhibits increasing in toxicity. This result indicates that the ethanolic extracts of Calotropis procera (leaves) and Citrullus colocynthis (fruits) contain highly anti-carcinogenic bioactive compounds other than the antioxidant compounds not correlated to the antioxidant activity.

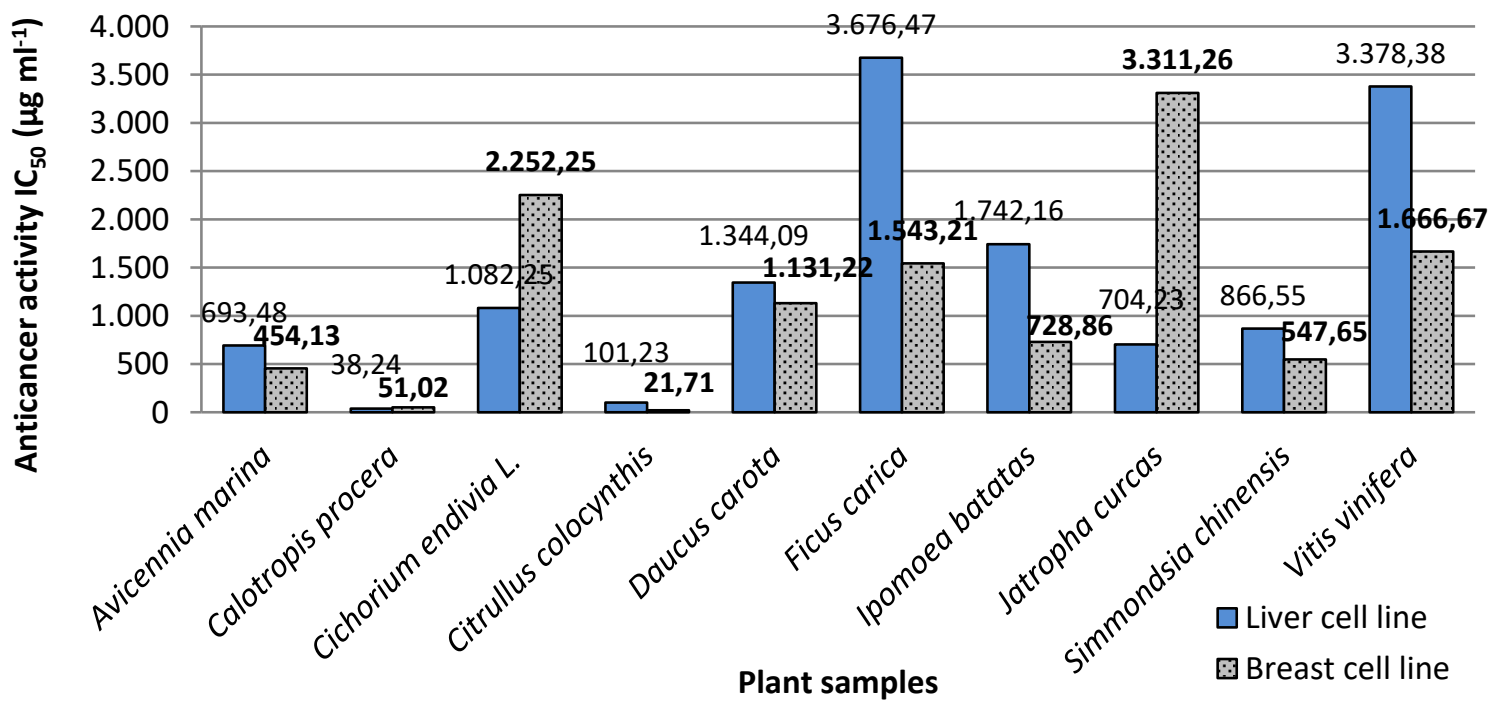

Figure 6. In vitro cytotoxicity assay $\mathrm{IC}_{50}\left(\mu \mathrm{g} \mathrm{ml}^{-1}\right)$ on liver and breast cell lines by the neutral red method of 10 plant samples. 
The Pearson's correlation coefficient between antioxidant activity by DPPH method and cytotoxicity of extracts against two types of cancer cells revealed that there are weak correlations (Figure 7). That's may be due to the specificity of compounds structure that has an anti-carcinogenic effect and needing for oxidative stress work on cancer cells to be damaged. [54] indicated the different results, which revealed a positive linear relationship between antioxidant scavenging activity and anticancer cytotoxic effect of the five herbal water extracts. This suggested that the antioxidants of the herbal water extracts might contribute to their anticancer cytotoxic effects on MCF-7 cells $\left(\mathrm{R}^{2}=0.7309\right)$. The use of different samples in our study showed the importance of dissects the mechanistic functions between antioxidant power and other anticancer activity compounds in herbs.
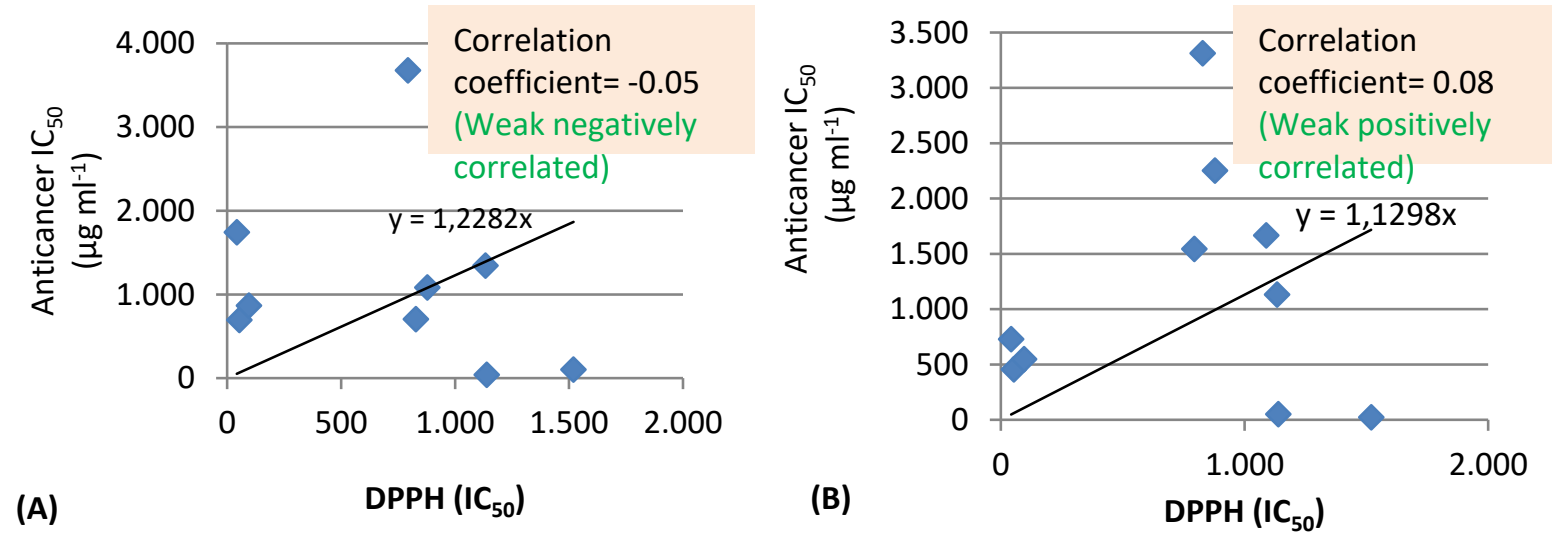

Figure 7. Correlation between antioxidant activity by DPPH method and anticancer $\mathrm{IC}_{50}\left(\mu \mathrm{g} \mathrm{ml} \mathrm{l}^{-1}\right)$ against carcinogenic liver and breast cells; (A) liver cells; (B) breast cells.

\subsubsection{The correlation between antioxidant activity and microbial cells cytotoxicity.}

The screening tests of EE regarding the inhibition zone were carried out by the well diffusion method against six types of microbes (Aspergillus fumigatus and Candida albicans (fungi), Staphylococcus aureus and Bacillus subtilis (gram-positive bacteria), Escherichia coli and Proteus vulgaris (gram-negative bacteria). The results are shown in Table 4.

Table 4. Antimicrobial activity of 10 plant samples.

\begin{tabular}{|c|c|c|c|c|c|c|}
\hline \multirow{3}{*}{ Plant samples } & \multicolumn{6}{|c|}{ Tested microorganisms } \\
\hline & \multicolumn{2}{|c|}{ Fungi } & \multicolumn{2}{|c|}{ Gram-positive bacteria } & \multicolumn{2}{|c|}{ Gram-negative bacteria } \\
\hline & \begin{tabular}{|l|}
$\begin{array}{l}\text { Aspergillus } \\
\text { fumigatus }\end{array}$ \\
\end{tabular} & $\begin{array}{l}\text { Candida } \\
\text { albicans }\end{array}$ & $\begin{array}{l}\text { Staphylococcus } \\
\text { aureus }\end{array}$ & Bacillus subtilis & $\begin{array}{l}\text { Escherichia } \\
\text { coli }\end{array}$ & Proteus vulgaris \\
\hline A. marina & NA & NA & NA & $8.00 \pm 0.17 \mathrm{~g}$ & NA & $12.07 \pm 0.12 \mathrm{~d}$ \\
\hline C. procera & NA & NA & NA & $10.20 \pm 0.25 \mathrm{f}$ & $7.93 \pm 0.35 \mathrm{c}$ & NA \\
\hline C. endivia L. & NA & NA & $9.90 \pm 0.26 \mathrm{~cd}$ & $14.93 \pm 0.18 \mathrm{c}$ & $9.73 \pm 0.37 b$ & $12.90 \pm 0.32 \mathrm{c}$ \\
\hline C. colocynthis & NA & NA & NA & NA & NA & NA \\
\hline D. carota & NA & NA & $7.73 \pm 0.37 \mathrm{e}$ & $11.97 \pm 0.32 \mathrm{e}$ & $9.97 \pm 0.26 \mathrm{~b}$ & $10.83 \pm 0.27 \mathrm{e}$ \\
\hline F. carica & NA & NA & $14.83 \pm 0.44 \mathrm{~b}$ & $16.97 \pm 0.38 \mathrm{~b}$ & $9.00 \pm 0.17 \mathrm{bc}$ & $13.93 \pm 0.23 \mathrm{~b}$ \\
\hline I. batatas & $8.07 \pm 0.18 \mathrm{c}$ & NA & NA & $12.73 \pm 0.37 \mathrm{e}$ & NA & $10.80 \pm 0.42 \mathrm{e}$ \\
\hline J. curcas & $7.97 \pm 0.15 \mathrm{c}$ & NA & $8.83 \pm 0.22 \mathrm{de}$ & $13.70 \pm 0.35 \mathrm{~d}$ & NA & NA \\
\hline S. chinensis & NA & NA & NA & $12.10 \pm 0.21 \mathrm{e}$ & NA & NA \\
\hline V. vinifera & $9.93 \pm 0.23 \mathrm{~b}$ & NA & $11.00 \pm 0.58 \mathrm{c}$ & $13.97 \pm 0.32 \mathrm{~d}$ & $8.23 \pm 0.28 \mathrm{c}$ & $11.87 \pm 0.19 \mathrm{~d}$ \\
\hline Positive control & $17.07 \pm 0.03 \mathrm{a}$ & $20.13 \pm 0.07$ & $24.03 \pm 0.03 \mathrm{a}$ & $26.13 \pm 0.09 \mathrm{a}$ & $30.03 \pm 0.09 \mathrm{a}$ & $25.03 \pm 0.09 \mathrm{a}$ \\
\hline
\end{tabular}

As presented in Figure 8, the correlation between antioxidant activity $\mathrm{IC}_{50}$ and in-vivo microbial cytotoxicity showed a weak correlation with Aspergillus fumigatus (A), Bacillus subtilis (C), and Proteus vulgaris (E) with Pearson's correlation coefficient of $-0.10,-0.28$, and 
-0.21, respectively and moderately correlation with Staphylococcus aureus (B) and Escherichia coli (D) with weak Pearson's correlation coefficient of 0.33 and 0.37 , respectively. On the other hand, the results showed by [55] indicated that plants with high antioxidant properties have high antimicrobial activity too. The correlation results suggested that the antimicrobial activity may be due to the different chemical constituents of different plant extracts besides the phenolic compounds.
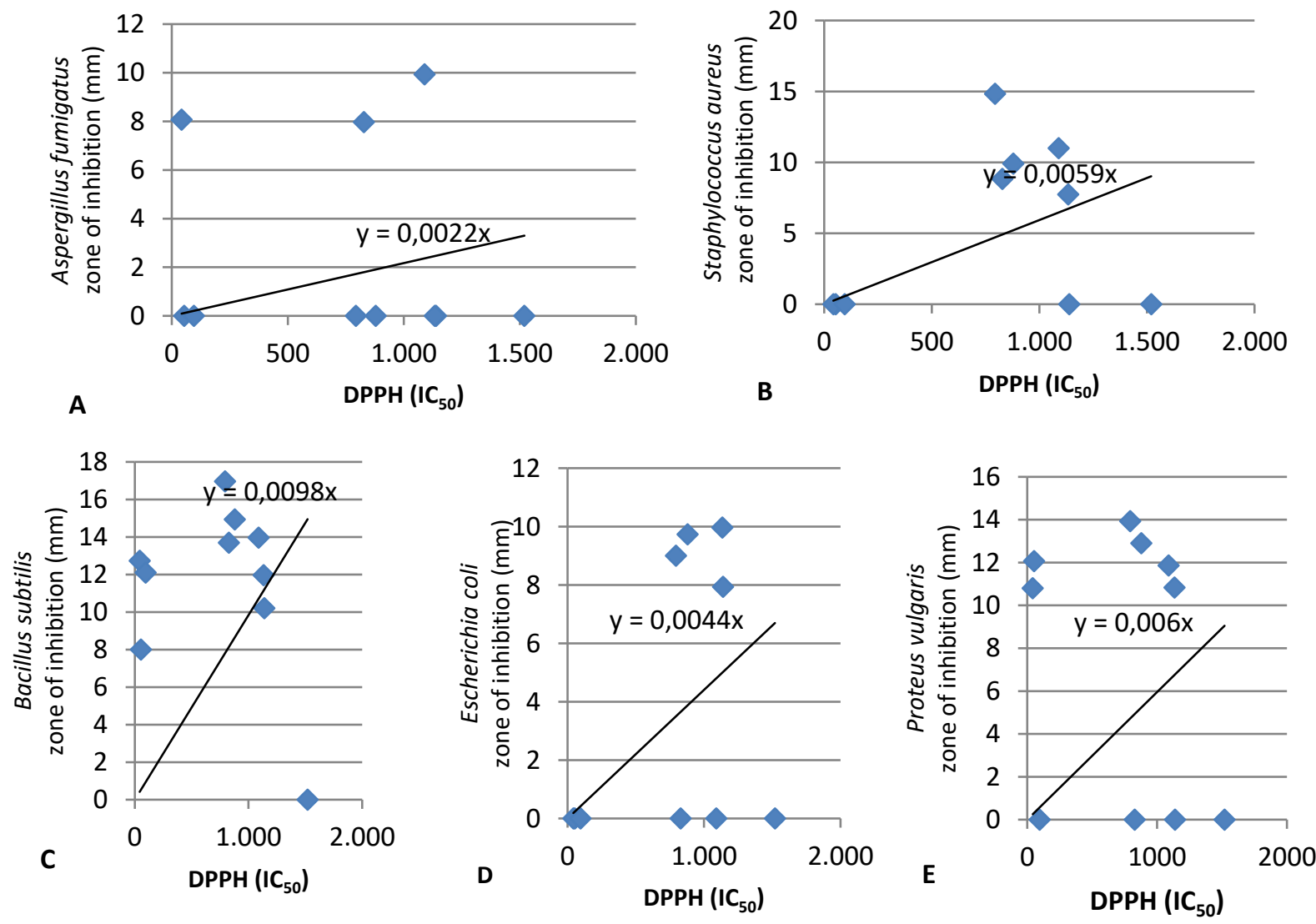

Figure 8. Correlation between antioxidant activity by DPPH method and antimicrobial activity zone of inhibition; (A) Aspergillus fumigatus; (B) Staphylococcus aureus; (C) Bacillus subtilis; (D) Escherichia coli;

(E) Proteus vulgaris.

\section{Conclusions}

In the present study, the correlation between antioxidant activity and cytotoxicity of ethanolic extracts of 10 plant samples were analyzed. The results indicated that there is a strong correlation between ABTS and DPPH methods, which are commonly used for the determination of antioxidant activity; there is a strong negative correlation between $\mathrm{IC}_{50}$ by DPPH method and total phenolic content. The Pearson's correlation coefficient between DPPH radical scavenging activity ( $\mathrm{IC}_{50}$ ) and cytotoxic in vivo or in vitro assays (the anticancer activity of -0.05 or 0.08 in liver and breast cell lines respectively which mean no correlation, brine shrimp cytotoxicity assay of 0.62 which mean moderately correlated and antimicrobial activity which showed moderate or weak or no correlations). These results proved that the mechanisms of cytotoxicity occurred in different ways that are not dependent only on the radical scavenging activity but also on the structure and nature of such other compounds.

\section{Funding}

This research received no external funding. 


\title{
Acknowledgments
}

\section{We thank prof. Kassem Fouad Kassem El-Sahhar (Department of Agricultural Botany, Faculty of Agriculture, Cairo University) for his valuable advices.}

\section{Conflicts of Interest}

\author{
The authors declare no conflict of interest.
}

\section{References}

1. Hossain, M.I.; Sharmin, F.A.; Akhter, S.; Bhuiyan, M.A.; Shahriar, M. Investigation of cytotoxicity and invitro antioxidant activity of Asparagus racemosus root extract. Int. Curr. Pharm J. 2012, 1, 250-257, https://doi.org/10.3329/icpj.v1i9.11615.

2. Woraratphoka, J.; Intarapichet, K.O.; Indrapichate, K. Antioxidant activity and cytotoxicity of six selected, regional, Thai vegetables. Am.-Eurasian J. Toxicol. Sci. 2012, 4, 108-117.

3. Eddebbagh, M.; Messaoudi, M.; Abourriche, A.; Berrada, M.; Attaleb, M.; Benbacer, L.; Bennamara, A. Correlation of the cytotoxic and antioxidant activities of moroccan pomegranate (Punica granatum) with phenolic and flavonoid contents. J. Pharm. Pharmacol. 2016, 4, 511-519, https://doi.org/10.17265/23282150/2016.09.006.

4. Bernstein, N.; Akram, M.; Daniyal, M.; Koltai, H.; Fridlender, M.; Gorelick, J. Antiinflammatory potential of medicinal plants: A source for therapeutic secondary metabolites. In: Advances in Agronomy. Academic Press. 2018; Volume 150, pp. 131-183, https://doi.org/10.1016/bs.agron.2018.02.003.

5. Gandhi, G.R.; de Sousa Leão, G.C.; da Silva Calisto, V.K.; Vasconcelos, A.B.S.; Almeida, M.L.D.; Quintans, J.D.S.S.; Barreto, B.; Narain, N.; Júnior, L.J.Q; Gurgel, R.Q. Modulation of interleukin expression by medicinal plants and their secondary metabolites: a systematic review on anti-asthmatic and immunopharmacological mechanisms. Phytomedicine https://doi.org/10.1016/j.phymed.2020.153229.

6. Waris, G; Ahsan, H. Reactive oxygen species: role in the development of cancer and various chronic conditions. Carcinogenesis 2006, 5, 14-22, https://doi.org/10.1186/1477-3163-5-14.

7. Melaku, L.S.; Worku, D. Role of long term oxidative stress in pathobiology of atherosclerosis with evaluation of enzymes involved in the production of endogenous reactive oxygen species. J. Med. Allied Sci. 2020, 10, 43-51, https://doi.org/10.5455/jmas.91137.

8. Zhazykbayeva, S.; Pabel, S.; Mügge, A.; Sossalla, S.; Hamdani, N. The molecular mechanisms associated with the physiological responses to inflammation and oxidative stress in cardiovascular diseases. Biophys. Rev. 2020, 12, 947-968, https://doi.org/10.1007/s12551-020-00742-0.

9. Da Silva, J.F.M.; de Souza, M.C.; Matta, S.R.; de Andrade, M.R.; Vidal, F.V.N. Correlation analysis between phenolic levels of Brazilian propolis extracts and their antimicrobial and antioxidant activities. Food Chem. 2006, 99, 431-435, https://doi.org/10.1016/j.foodchem.2005.07.055.

10. Kim, I.S.; Yang, M.; Lee, O.H.; Kang, S.N. The antioxidant activity and the bioactive compound content of Stevia rebaudiana water extracts. LWT 2011, 44, 1328-1332, https://doi.org/10.1016/j.lwt.2010.12.003.

11. de Oliveira, N.K.; Almeida, M.R.S.; Pontes, F.M.M.; Barcelos, M.P.; de Paula da Silva, C.H.T.; Rosa, J.M.C.; Cruz A.R.S.; da Silva Hage-Melim, L.I. Antioxidant effect of flavonoids present in Euterpe oleracea Martius and neurodegenerative diseases: A literature review. Cent Nerv Syst Agents Med Chem. (Formerly Current Medicinal Chemistry-Central Nervous System Agents) 2019, 19, 75-99, https://doi.org/10.2174/1871524919666190502105855.

12. Gu, C.; Howell, K.; Dunshea, F.R.; Suleria, H.A. LC-ESI-QTOF/MS characterisation of phenolic acids and flavonoids in polyphenol-rich fruits and vegetables and their potential antioxidant activities. Antioxidants 2019, 8, 405-420, https://doi.org/10.3390/antiox8090405.

13. Kaurinovic, B.; Vastag, D. Flavonoids and phenolic acids as potential natural antioxidants. In: Antioxidants. IntechOpen. 2019, https://doi.org/10.5772/intechopen.83731.

14. Tanleque-Alberto, F.; Juan-Borrás, M.; Escriche, I. Antioxidant characteristics of honey from Mozambique based on specific flavonoids and phenolic acid compounds. J Food Compost Anal. 2020, 86, https://doi.org/10.1016/j.jfca.2019.103377.

15. Kaur, C.; Kapoor, H.C. Antioxidants in fruits and vegetables-the millennium's health. Int. J. Food Sci. Technol. 2001, 36, 703-725, https://doi.org/10.1111/j.1365-2621.2001.00513.x.

16. Goorani, S.; Zangeneh, M.M.; Koohi, M.K.; Seydi, N.; Zangeneh, A.; Souri, N.; Hosseini, M.S. Assessment of antioxidant and cutaneous wound healing effects of Falcaria vulgaris aqueous extract in Wistar male rats. Comp Clin Path. 2019, 28 435-445, https://doi.org/10.1007/s00580-018-2866-3.

17. Singh, S.K.; Srivastav,S.; Castellani, R.J.; Plascencia-Villa, G.; Perry, G. Neuroprotective and antioxidant effect of Ginkgo biloba extract against AD and other neurological disorders. Neurotherapeutics 2019, 16, 19, https://doi.org/10.1007/s13311-019-00767-8. 
18. Barghout, N.; Chebata, N.; Moumene, S.; Khennouf, S.; Gharbi, A.; El Had, D.I. Antioxidant and antimicrobial effect of alkaloid bulbs extract of Polianthes tuberosa L.(Amaryllidaceae) cultivated in Algeria. J. Drug Deliv. Ther. 2020, 10, 44-48, https://doi.org/10.22270/jddt.v10i4.4134

19. Ciampi, F.; Sordillo, L.M.; Gandy, J.C.; Caroprese, M.; Sevi, A.; Albenzio, M.; Santillo, A. Evaluation of natural plant extracts as antioxidants in a bovine in vitro model of oxidative stress. J. Dairy Sci. 2020, 103, 8938-8947, https://doi.org/10.3168/jds.2020-18182.

20. Ben Mrid, R.; Bouchmaa, N.; Bouargalne, Y.; Ramdan, B.; Karrouchi, K.; Kabach, I.; El Karbane, M.; Idir, A.; Zyad, A.; Nhiri, M. Phytochemical Characterization, Antioxidant and In Vitro Cytotoxic Activity Evaluation of Juniperus oxycedrus Subsp. oxycedrus Needles and Berries. Molecules 2019, 24, 502-520, https://doi.org/10.3390/molecules24030502.

21. Kuete, V.; Wiench, B.; Hegazy, M.E.F.; Mohamed, T.A.; Fankam, A.G.; Shahat, A.A.; Efferth, T. Antibacterial activity and cytotoxicity of selected Egyptian medicinal plants. Planta Med.. 2012, 78, 193199, http://dx.doi.org/10.1055/s-0031-1280319

22. Lincy, M.P.; Paulpriya, K.; Mohan, V.R. In vitro antioxidant activity of Avicennia marina (Forssk) vierh pneumatophore (Avicenniaceae). Science Research Reporter. 2013, 3, 106-114.

23. Zhang, L.; Tu, Z.C.; Yuan, T.; Wang, H.; Xie, X.; Fu, Z.F. Antioxidants and $\alpha$-glucosidase inhibitors from Ipomoea batatas leaves identified by bioassay-guided approach and structure-activity relationships. Food chemistry. 2016, 208, 61-67, https://doi.org/10.1016/j.foodchem.2016.03.079.

24. Baccouch, N.; Salah, H.B.; Belhaj, S.; Hentati, O.; Abdennabi, R.; Gharsallah, N.; Elfeki, A.; Ayedi, M.; Allouche, N. Chemical characterization and biological activities of Simmondsia chinensis (Link) CK Schneid seeds oil. Cell. Mol. Biol. (Noisy-le-Grand, France) 2018, 64, 11-16, http://dx.doi.org/10.14715/cmb/2018.64.4.3.

25. Liu, H.; Wang, Q.; Liu, Y.; Chen, G.; Cui, J. Antimicrobial and antioxidant activities of Cichorium intybus root extract using orthogonal matrix design. J. Food Sci.. 2013, 78, M258-M263, https://doi.org/10.1111/1750-3841.12040.

26. Mahmoudi, S.; Khali, M.; Benkhaled, A.; Benamirouche, K.; Baiti, I. Phenolic and flavonoid contents, antioxidant and antimicrobial activities of leaf extracts from ten Algerian Ficus carica L. varieties. Asian Pac. J. Trop. Biomed. 2016, 6, 239-245, https://doi.org/10.1016/j.apjtb.2015.12.010.

27. Simonetti, G.; D’Auria, F.D.; Mulinacci, N.; Milella, R.A.; Antonacci, D.; Innocenti, M.; Pasqua, G. Phenolic content and in vitro antifungal activity of unripe grape extracts from agro-industrial wastes. Nat. Prod. Res. 2019, 33, 803-807, https://doi.org/10.1080/14786419.2017.1410811

28. Zazharskyi, V.V.; Davydenko, P.O.; Kulishenko, O.M.; Borovik, I.V.; Brygadyrenko, V.V. Antimicrobial activity of 50 plant extracts. Biosyst. Divers. 2019, 27, 163-169, https://doi.org/10.15421/011922.

29. Alzahrani, H.S.; Almalki, S.A.; Rizgallah, M.R. Study of the cytotoxic effect of Calotropis procera on Breast Cancer Cell Line, T47D in Vitro: A Traditional Remedy. Int. J. Sci. Innovs. 2019, 7, 107-112.

30. Gaikwad, M.; Shirsat, V.; Bulbule, M.; Kalekar, S.; Munshi, R. Ethyl acetate extract of Citrullus colocynthis (Linn.) Schrad. fruit suppresses angiogenesis. J Pharm Pharmacogn Res. 2019, 7, 331-342.

31. Purnamasari, R.; Winarni, D.; Permanasari, A.A.; Agustina, E.; Hayaza, S.; Darmanto, W. Anticancer activity of methanol extract of Ficus carica leaves and fruits against proliferation, apoptosis, and necrosis in Huh7it cells. Cancer Inform. 2019, 18, 1-7, https://doi.org/10.1177/1176935119842576.

32. Malekzadeh, R.; Arjmand, M.; Haji Hosseini, R.; Vaziri, A.; Zamani, Z. Evaluation of the Anticancer Effect of Xanthium Strumarium Root Extract on Human Epithelial Ovarian Cancer Cells Using 1H NMR-Based Metabolomics. J. Sci. Islam. Repub. Iran. 2020, 31, 205-212, https://doi.org/10.22059/jsciences.2020.291407.1007458.

33. Zaini, R.; Clench, M.R.; Le Maitre, C.L. Bioactive chemicals from carrot (Daucus carota) juice extracts for the treatment of leukemia. J. Med. Food. 2011, 14, 1303-1312, https://doi.org/10.1089/jmf.2010.0284.

34. Katalinic, V.; Mozina, S.S.; Generalic, I.; Skroza, D.; Ljubenkov, I.; Klancnik, A. Phenolic profile, antioxidant capacity, and antimicrobial activity of leaf extracts from six Vitis vinifera L. varieties. Int. J. Food Prop. 2013, 16, 45-60, https://doi.org/10.1080/10942912.2010.526274.

35. Harbone, J.B. Phytochemicals methods. London. Chapman and Hill. Ltd, 1973; pp. 49-118.

36. Hanson, J.R. Chemistry of terpenes and terpenoids. (Ed.A.A. Newman). Academic press. New York, 1972; pp. 155-206.

37. Paris, R.; Moyse, H. Precis de matieremedicinale. Paris: Masson. 1969.

38. Rizk, A.M. Constituents of plants growing in Qatar: A chemical survey of sixty plants. Fitoterapia 1982, 52, 35-44

39. Peach, K.; Tracey, M.V. Modern methods of plant analysis. Springer Verlag, Berlin, Volume 3, 1956.

40. Singleton, V.L.; Rossi J, A. Jr. Colorimetry of total phenolics with phosphomolybdic-phosphotungstic acid reagents. Am. J. Enol. Vitic. 1965, 16, 144-158.

41. Blois M.S. Antioxidant determinations by the use of a stable free radical. Nature 1958, 181, 1199-1200, https://doi.org/10.1038/1811199a0.

42. Re, R.; Pellegrini, N.; Proteggenate, A.; Pannala, A.; Yang, M.; Rice-Evans, C. Antioxidant Activity Applying an Improved ABTS Radical Cation Decolorization Assay. Free Radic. Biol. Med. 1999, 26, 12311237, https://doi.org/10.1016/S0891-5849(98)00315-3. 
43. Meyer, B.N.; Ferrigni, N.R.; Putnam, J.E.; Jacobsen, L.B.; Nichols, D.J.; McLaughlin, J.L. Brine shrimp: a convenient general bioassay for active plant constituents. Planta Med. 1982, 45, 31-34, https://doi.org/10.1055/s-2007-971236.

44. Repetto, G.; Del Peso, A.; Zurita, J.L. Neutral red uptake assay for the estimation of cell viability/cytotoxicity. Nat. Protoc. 2008, 3, 1125-1131, https://doi.org/10.1038/nprot.2008.75.

45. National Committee for Clinical Laboratory Standards (NCCLS). Performance Standards for Antimicrobial Disc Susceptibility Tests. Approved Standard NCCLS Publication, Villanova, PA, USA, 1993; pp. M2-A5.

46. Hindler, J.A.; Howard, B.J.; Keiser, J.F. Antimicrobial agents and Susceptibility testing, In: Clinical and pathogenic Microbiology. Howard, B.J. (Editor); Mosby-Year Book Inc., St. Louis, MO, USA, 1994; pp. 145-195.

47. Ratner, B. The correlation coefficient: Its values range between $+1 /-1$, or do they? J Target Meas Anal Market. 2009, 17, 139-142, https://doi.org/10.1057/jt.2009.5.

48. Khafagi, I.; Gab-Alla, A.; Salama, W.; Fouda, M. Biological activities and phytochemical constituents of the gray mangrove Avicennia marina (Forssk.) Vierh. Egypt. J. Bot. 2003, 5, 62-69.

49. Huang, C.; Lu, C.K.; Tu, M.C.; Chang, J.H.; Chen, Y.J.; Tu, Y.H.; Huang, H.C. Polyphenol-rich Avicennia marina leaf extracts induce apoptosis in human breast and liver cancer cells and in a nude mouse xenograft model. Oncotarget. 2016, 7, 35874-35893, https://doi.org/10.18632/oncotarget.8624.

50. Ho, Y.L.; Huang, S.S.; Deng, J.S.; Lin, Y.H.; Chang, Y.S.; Huang, G.J. In vitro antioxidant properties and total phenolic contents of wetland medicinal plants in Taiwan. Bot Stud. 2012, 53, 55-66.

51. Shalaby, E.A.; Shanab, S.M. Comparison of DPPH and ABTS assays for determining antioxidant potential of water and methanol extracts of Spirulina platensis. Indian J Geo-Mar Sci. 2013, 42, 556-564.

52. Dudonne, S.; Vitrac, X.; Coutiere, P.; Woillez, M.; Merillon, J.M. Comparative study of antioxidant properties and total phenolic content of 30 plant extracts of industrial interest using DPPH, ABTS, FRAP, SOD, and ORAC assays. J. Agric. Food Chem. 2009, 57, 1768-1774, https://doi.org/10.1021/jf803011r.

53. Ghasemi, K.; Ghasemi, Y.; Ebrahimzadeh, M.A. Antioxidant activity, phenol and flavonoid contents of 13 citrus species peels and tissues. Pak J Pharm Sci. 2009, 22, 277-281.

54. Li, W.Y.; Chan, S.W.; Guo, D.J.; Yu, P.H.F. Correlation between antioxidative power and anticancer activity in herbs from traditional Chinese medicine formulae with anticancer therapeutic effect. Pharm. Biol. 2007, 45, 541-546, https://doi.org/10.1080/13880200701498879.

55. Fazeli-Nasab, B.; Rahnama, M.; Mazarei, A. Correlation between antioxidant activity and antibacterial activity of nine medicinal plant extracts. J Mazandaran Univ Med Sci. 2017, 27, 63-78. 